Stage Tricks

Previous: Letter from the Editors by Thom Bryce, Kate Siklosi, Nemanja Protic

Next: "if buizy Love intrenches": Adorno and Rochester on Pleasure and Love by Lacey Ann Conley

\title{
Stage Tricks:
}

Handling Props in Arden of Faversham

Bernice Mittertreiner Neal

Pivot is published through Open Journal Systems (OJS) at York University 
"More than anything else, I am trying to 'exaggerate' the medium of theatre, its affective corporeality as the carrier of meanings." 1

Forgive me, Arden; I repent me now;

And, would my death save thine, thou shouldst not die.

$(16.7-8)^{2}$

An early modern boy actor delivers two lines of his text, above, near the end of The Tragedy Stage Tricks:

\section{Handling Props in Arden of Faversham}

Bernice Mittertreiner Neal of Master Arden of

Faversham (1591) in his role as an adulteress, Alice Arden, who gazes in repentance at the bleeding body of her husband, Thomas Arden, whom she has just murdered. ${ }^{3}$ Performed on the Elizabethan, and newly secular, English stage in the wake of the Reformation, this play employs what I shall call the Corpus Christi affect-a phenomenon from the outlawed medieval theatre-to play a trick on its staring and startled audience. The stage trick is the theatrical effect of the phenomenon: an apparently irredeemably malicious and shameful Mistress Arden, a dramatic character based on a real-life counterpart condemned to death for her actions, thereby finds salvation. The Corpus Christi affect is a theatrical mode of medieval theatre that may offer salvific ocular experience to its spectators, should an actor choose to

\footnotetext{
${ }^{1}$ Bert O. States, Great Reckonings in Little Rooms: On the Phenomenology of Theater, 27.

2 The Tragedy of Master Arden of Faversham, ed. M. L. Wine. Subsequent citations in the text are to this edition unless otherwise noted.

${ }^{3}$ Wine reports, "no record exists of an actual performance before the eighteenth century. There are several indications, however, that the play enjoyed an active stage history before its publication in 1592 and continuously thereafter" (xlv).
} 
perform, and a spectator happen to perceive, in that mode. The Corpus Christi affect relies for its efficacy on the "affective corporeality," in Arden, of a body and blood on the stage, both handled as stage properties by actors.

I pay attention to the distinction and relationship between playtext, actor, and performance. I distinguish between role"the words of the playtext ... and the actions implied by those words"-and character, which "emerges as the actor decides how to use the materials of the role, making the moment-bymoment choices that create a reading of that role" (O'Brien 17). Positing the boy actor for the female role of Alice Arden helps me clarify these distinctions between his and her actions in my readings of the playtext. Finally, I consider the place and experience of the play's spectators. Here, I adopt an approach Michael Mooney takes to the problems of imagining actors' choices and spectators' responses, particularly to a historical stage, in Shakespeare's Dramatic Transactions. Here, Mooney asserts "the potential riches ... to be found in Shakespeare's manipulation of the spectators" (6). While Mooney acknowledges that "there can never be a fixed meaning for a work of art," nevertheless, he argues, "Meaning has always depended upon the perceiving eye. The possible reactions built into a Shakespearean play make meaning a product of the communicative act, of the playwright's and the actors' intention and of the audience's response" (6). My work with an imagined spectator and how she might respond to what she sees and hears lets me articulate potential effects of the boy actor's negotiation with a contingent and unstable playtext such as Arden of Faversham.

On February 15, 1551, the real Alyce Ardern murdered her husband, Thomas Ardern of Faversham, merchant and landlord, in their own parlour. Mistress Ardern drew some of Master Ardern's own servants and business colleagues into 
her plot. The murderers carried the corpse out into the meadows at the back of the Ardern's garden. Alyce Ardern was tried and convicted, sentenced to die, and burnt at the stake in Canterbury. In the 1570s, Holinshed chronicled the crimes and sentencing related to this murder, and some twenty years later an anonymous playwright dramatized the history in a domestic tragedy, The Tragedy of Arden of Faversham. The plot of the play is labyrinthine, and the cast of characters full of tricksters. Willful, desiring, and devious heroine Alice, who seduces her double-dealing lover Mosby by repudiating her marriage oath as mere words, and two comically anarchic thieves, the suspiciously named Black Will and Shakebag, are thwarted repeatedly by the apparent sheer good luck of Thomas Arden. The play's spectacle is my particular focus-a poisoned crucifix, a painting that kills at a glance, a prayerbook shorn of its leaves-spectacle that insistently points at and exploits anxieties that motivate the iconophobes and the iconoclasts.

Russell A. Fraser declares that "the rude handling of sacred totems is what [Tudor] drama is all about" (3). Andrew Sofer cites Fraser's comment as an "apt summation of the two-way traffic between spiritual and secular concerns on the early modern stage" in his discussion of the "thoroughly irreverent use of props" in the medieval Corpus Christi plays that inform it (34). I propose to look at the rude handling of sacred totems in Arden to consider the affective prompts that the play may thus have in store for a spectator. I employ Sofer's analysis of the journeys that stage properties track throughout any given performance. He proposes how props can function in ways that are less passive than their use as metaphors for characterization, as more than just "visual shorthand" (20-22). Rather, they may achieve a kind of autonomy in a "mode of 'semiotic subjectivity,'" where they "transcend their customary roles as transparent scenic metonymies and expository signs" (24). While Alice's 
blasphemy, rebellion, and felony appear to be contained and condemned by her death sentence, ${ }^{4}$ I argue that the play stages its own subversive act by asserting the corpse of her husband as potentially salvific by means of the Corpus Christi affect. Stage magic affords a way for Alice to perform her spiritual redemption and escape the containment the play constructs for her with her staged prosecution. This staging trick that lays in wait for a spectator can offer her an experience of reading semiotic signs that profess Alice judged, found guilty, and condemned. At the same time, the phenomenology of the stage provides an actor playing Alice a way, should he choose to do so, to disclose the bleeding corpse to her affectively, offering her a catharsis by wonder.

One question the play asks is why should sacred totems be rudely handled? The Oxford Dictionary of Philosophy's definition of iconoclasm provides an answer to that question: "The odd pair of beliefs shared by enthusiasts including Cromwell and the Taliban, that while 'false idols' have no supernatural powers they are nevertheless so dangerous that they must be destroyed rather than ignored" (177). False idols simply cannot be left alone because they compel a subject's gaze. Marguerite A. Tassi ${ }^{5}$ describes how "Elizabethans were as much in love with images, as they were fearful of the dangerous powers attributed to them" (29). She locates the Elizabethan desiring gaze in the theatre in the context of medieval religious drama:

The newly built theaters featured excellent actors who fed people's eyes with fancies and spectacles. What was

\footnotetext{
${ }^{4}$ Elizabeth Williamson notes as well that the play "never allows Alice to carry out her threats" (393).

5 The Scandal of Images: Iconoclasm, Eroticism, and Painting in Early Modern English Drama. In her chapter devoted to Arden of Faversham, Tassi argues that dramatists exploited iconoclastic phobias directed specifically towards portraiture and painters to thereby differentiate and so defend their own art against antitheatrical argument.
} 
once, just a few decades earlier, a sacred theater that fostered a devotional (or idolatrous, according to the reformers) gaze in Christian worshippers had given way, by order of law, to a secular and commercial form of play that satisfied the curious, hungry gaze of "spectators" who gathered in a new kind of social arena. (35)

Tassi picks up Michael O'Connell's argument, ${ }^{6}$ which targets precisely the phenomenon that both iconoclasts and antitheatricalists fear the "idolatrous eye" of a spectator will perceive-presence: "The opposition to theater, like the hostility to graven images, reflects fear and anxiety about a state of mind that grants presence, i.e., the presence of a god, or another essence not made by God, to an image." A player kindled such alarm for he was thought to be himself, as Tassi explains, a "self-created image" (36, italics in the original). The actor's body was essentially a lie because it pretended to be something it was not, and anyone who wilfully impersonated another, or who watched another do so, was "engag[ing] in a dangerously sacrilegious business" (36). Of course, anxiety about a state of mind that grants presence is inextricably implicated in doctrinal differences over the Eucharist, the crisis that gave rise to the great body of dramatic theatre called the Corpus Christi or Mystery plays. Catholic doctrine asserts that the consecrated host is the body of Christ, that the communion wine is the blood of Christ, and that Christ is present in both, as opposed to nonCatholic beliefs that Christ is variously represented by these objects.

Sofer takes up the contested ontological status of the elevated host to define competing phenomenological and semiotic attitudes towards stage properties: Catholic, Lutheran, Zwinglian (51), and Anglican attitudes (55). For an

${ }^{6}$ See The Idolatrous Eye. See also Jonah Barish, The Antitheatrical Prejudice. 
object on stage "to register as a prop," it "must be perceived by a spectator as a sign" (50). Sofer builds on Anthony B. Dawson's correlation between Anglican doctrine and the contract made between actor and spectator in performance $(56)^{7}$ to theorize "the ambiguity of the object's reception" (50):

Like a character, a theatrical sign is not a semiotic given but a temporal contract between actors and audience, in which identity is superimposed on a material object.

Such a contract is tenuously constituted in time and thus subject to moment-by-moment renegotiation for the duration of performance. (56-57, italics in the original) ${ }^{8}$

Sofer adopts Peter Brook's ${ }^{9}$ notion of how "an 'empty object' can be remarkably effective on stage in the hands of a skilled actor" (52), posits a water-bottle carried by an actor to represent a baby on a stage, and considers what a spectator's attitude might be to the water-bottle:

[T] he "Catholic" position, which denies representation, is untenable with regard to stage properties. ... [A] "Lutheran" spectator fuses semiotic and phenomenological perspectives and perceives both a bottle and a real baby (Brook's position); a "Zwinglian" spectator perceives a bottle that merely represents a baby, without getting swept up into the illusion; and an "Anglican" spectator accepts a virtual baby whose presence is (in Dawson's phrase) "unreal but also efficacious." (57)

Catholic and Zwinglian attitudes, then, are at definitive polar ends of ways that a spectator may perceive a prop's

\footnotetext{
7 "Performance and Participation: Desdemona, Foucault, and the Actor's Body," in Shakespeare, Theory, and Performance.

${ }^{8}$ As here, italics in subsequent citations to Sofer are all in the original.

9 There Are No Secrets: Thoughts on Acting and Theatre, 46.
} 
ontological status on stage. The Anglican attitude recognizes the materiality of the bread and the wine, but locates the occurrence of the sacrament in the recipient. The Lutheran attitude-consubstantiation rather than transubstantiationtranslates in theatrical terms imaginatively along the lines of Bert O. States's phenomenological approach, ${ }^{10}$ as Sofer acknowledges, where the bottle "'discloses' the baby to the audience as a unique, affective experience" (53).

Sofer makes an analogy between the efficacy of props in the theatre and "what theologians term receptionism, 'the doctrine that the efficacy of the consecrated elements depends upon the spiritual state of the communicant' rather than upon the transformed material substance of the object" (58). While, as Sofer says, the spectator "determines what sort of imaginative contract is entered into" (57), much depends on the actor's ability to endow the prop with meaning/identity, assuming that is what the actor's performance seeks to do. What choices, given the obligations of his dramatic text, does the actor carrying the bottle have in order to negotiate how he will perform, how he will carry the bottle? In this spirit of inquiry, I shall imagine how an actor might perform Alice's entrance, holding a prayerbook, in scene 8: that is, what options might he consider for holding that "water bottle," Alice's prayerbook? How might he make sense of lines that obligate him to declare that she will burn the book one moment and tear out its leaves the next? I do so in order to demonstrate how the playtext orchestrates, in Sofer's terms, a Lutheran consubstantive affective experience for its spectators in this scene that sets the stage for a miracle at the play's end. ${ }^{11}$

${ }^{10}$ Great Reckonings in Little Rooms: On the Phenomenology of Theater. 11 "They say miracles are past, and we have our philosophical persons to make modern and familiar things supernatural and causeless," remarks Lafeu to Bertram and Paroles upon news of the King's recovery in All's Well that Ends Well. As editor Susan Snyder notes, "According to 
Of course, a distinction between a baby and a water bottle is more apparent than is one between a prayerbook that is a prop on a stage and a prayerbook anywhere else. First, then, in order to consider how the prayerbook as stage property might signify on Arden's stage, let us turn for comparative purposes to two plays dated close to or at the same time as Arden: Shakespeare's 3 Henry VI (1590) and Richard III (1591). ${ }^{12}$ Both plays feature a prayerbook that is triggered by an actor into a stage property. In 3 Henry VI, a fugitive King Henry enters a thicket "with a prayer book" (3.1.12.1). No further mention is made of the item in the stage directions; no speech text refers to the book nor embeds any further gesture to be made with it. Editor Randall Martin notes that the prayerbook "suggests Henry's anti-worldly reasoning and 'wise folly', each of which the chronicles proffer as possible motives for his running away" (n. 12.1). Here then is an example of a prop that functions to externalize and give potential evidence for what is internal, therefore unseen and, in this case, apparently questionable-Henry's motive(s) for flight. Furthermore, the prop also serves to distinguish Henry from the two gamekeepers, who have already entered the scene "with cross-bows in their hands" (3.1.0.1). Props can thus function, as Lena Cowen Orlin suggests, to "fix identity" (190), ${ }^{13}$ and the gamekeepers' crossbows identify the two men as game hunters. Importantly, the characters themselves, the gamekeepers, make a metaphoric connection between their own occupation and/or weapons and Henry as "game": "Ay, here's a deer whose skin's a keeper's fee. / This is the quondam king; let's seize upon him" (3.1.22-23). In fact, the second gamekeeper later makes reference to what

Protestant doctrine, miracles ceased after New Testament times" ( $n$. 2.3.1).

${ }^{12}$ Citations from Shakespeare's plays are to Oxford World's Classics editions.

13 "The Performance of Things in The Taming of the Shrew." 
he perceives as a missing prop that marks and authenticates identity when he asks of Henry, "But if thou be a king, where is thy crown?" (61). Henry replies, "My crown is in my heart, not on my head" (62). These are characters who present an awareness of the semiotic significance of the objects they bear or attend to, and even those objects that are absent or missing.

Characters in Richard III present a similar awareness in the notably metatheatrical scenes where Richard plots how he may stage-manage an effective setting and cast list so as to prompt a recalcitrant citizen audience to support his claim to kingship. In 3.5, he instructs Buckingham to bring the citizens to Baynard's Castle, where he shall be "well accompanied / With reverend fathers and well-learnèd bishops (97-98); in 3.7, with the Mayor at hand, Buckingham advises Richard, "get a prayer book in your hand, / And stand betwixt two churchmen" (42-43). According to plan, when Richard enters "aloft" (3.7.89.2), the Mayor notices what Buckingham and Richard mean for him to notice. "See where he stands between two clergymen" (90), the observant Mayor remarks to Buckingham, who in turn instructs the Mayor on how that stage blocking signifies, how the clergymen relate to Richard: "Two props of virtue for a Christian prince, / To stay him from the fall of vanity" (91-92).

Buckingham's audacious pun on "props" divides both onstage characters and $R 3$ 's spectators. There are those onstage who (only) register Buckingham's intended meaning for the Mayor ${ }^{14}$-that the clergymen function to prop or shore up a Christian in the face of temptation; then, there are the other character-actors on the stage who are participating in the "Richard for King!" play. Spectators in the audience, too, may or may not register that the clergymen "indeed are 'props' in

${ }^{14}$ Even the actor playing the Mayor may choose to register the theatrical sense of the term. 
this blatantly 'staged' scene" (39), as Michael Mooney notes. ${ }^{15}$ The prayerbook and the clergymen are what Francis Teague (and Sofer after her) would call "speaking props" that identify Richard as a Christian and signify his piety. Both the Mayor's and Buckingham's words, however, emphasize their sight of the props. "See where he stands," says the Mayor (3.7.90); "And see, a book of prayer in his hand," says Buckingham (93), highlighting the props as visual evidence of what can otherwise not be seen-Richard's internal condition. For my purposes, what is key in both plays is twofold. First, props function here as a readable and external reflection or mirroring of a character's inner condition: Henry's motive, Richard's piety. Second, characters are aware of, and even use, the semiotic significance of objects strategically: the gamekeeper points out an absent crown to challenge Henry's claim to kingship; Richard holds and reads from a prayerbook to prompt the citizens' allegiance.

Let us turn back now to my question about how Alice in Arden of Faversham enters scene 8 and why she may be holding a prayerbook. Part of the interpretive problem lies with the playtext itself. Stage directions in the quarto edition that appeared in the same year (1592) that the title of the play was entered in the Register of the Stationers' Company read: "Here enters ALICE" (8.43.1); this edition makes no mention of a prayerbook. Editors of the 1973 edition (Wine) and the Revels Plays' 1999 edition (McLuskie and Bevington) reproduce editor K. Sturgess's addition (1969): "[holding a prayerbook]" (coll. 8.43.1). After all, as McLuskie and Bevington point out, she "needs the prayer book for her vow in line 116" (n. 43.1), where she declares to Mosby that she will "burn this prayerbook."

Certainly, Alice's actions in scene 1 give cause for a penitent turn. There, in her only monologue, Alice fantasizes a kind of

${ }^{15}$ See also Elizabeth Williamson, 382-86. 
magical, mythic death for Arden: "O, that some airy spirit / Would in the shape and likeness of a horse / Gallop with Arden 'cross the ocean / And throw him from his back into the waves!" (94-97). Alice thus creates her own mythology and, next, her own religion, wherein "Love is a god" (101). Since "[s]weet Mosby is the man that hath my heart" (98), she determines that "therefore Mosby's title is the best" (102). Since for Alice "marriage is but words" (101), her husband, Arden, "usurps" her "heart" $(99,98)$. However, scene 8 opens with Mosby meditating alone upon his own "troubled mind ... stuffed with discontent" (10). He lets us know, in a manner most Vice-like, that he will make use of and dispense with Greene, as he will with Michael and the painter, and finally, with "Mistress Arden" herself: "And I will cleanly rid my hands of her" $(37,43)$. His motives and intentions, delivered to us in direct address, are no mystery to us. The same cannot be said of Alice.

As she enters the scene (8.43.1), holding a prayerbook, as our editors advise, a spectator is left to interpret Alice's intentions according to how she overhears Alice's dialogue with Mosby and how she sees Alice perform. Mosby exclaims, "What, sad and passionate?" (45) and Alice tells Mosby her intent and her motive-she "will dam that fire in my breast" (48) for Arden loved her "dearly" (61)-before she proposes that they part:

I pray thee, Mosby, let our springtime wither;

Our harvest else will yield but loathsome weeds.

Forget, I pray thee, what hath passed betwixt us,

For now I blush and tremble at the thoughts. (66-69)

Her repetition of "I pray thee" and her performance, blushing and trembling at "the thoughts" of what passed between them, may suggest that she has taken a spiritual audit of her actions. She may feel remorse over committing adultery and acting "[i]n spite of [Arden], of Hymen, and of rites" (1.104). 
She may repent the extent of her profane love entirely, that even "Arden to me was dearer than my soul" (1.197). Thus her rejection of Mosby and her reading of a prayerbook are both part of her penance. In this scenario, she genuinely uses the prayerbook for its intended and conventionally recognized use, and the actor handles the prop as an external sign that points to her inner state-contrition, and her motivepenance.

Alice may also be deliberately manipulating the signifying quality of a prayerbook, using the prayerbook as a prop to demonstrate her change of mind-she will not kill Arden, she will honour her marital vows, she has undergone a religious conversion and is penitent-to Mosby. She may even be faking her own religious conversion as a means of persuading Mosby to abandon their course of action, in which case the prayerbook as prop would here "substantiate deceit" (Orlin 190). Elizabeth Williamson takes up the particular problems that prayerbooks as stage properties-"mere thing[s] without any intrinsic value" (394)-posed and highlighted on the early modern stage, including the possibility of women's "abuse of religious objects" (387). ${ }^{16}$ Williamson neatly parallels the potential on the parts of both stage actor and congregant, Protestant and Catholic alike, "to express an inner faith through bodily gestures and material objects" (372). Her argument foregrounds how "[s]ome plays ... prompted spectators to draw a ... radical set of conclusions-namely, that worship could all too easily be interpreted as an 'act' because devotion, like playacting, required a set of bodily gestures as well as a recognizable prop" (374). Williamson assigns motive on the part of Arden's Alice based on her handling of the prayerbook and considers the implications of that action for how the play communicates with its spectator:

16 "The Uses and Abuses of Prayer Book Properties in Hamlet, Richard III, and Arden of Faversham." 
Alice "uses her prayer book to impress her lover with her lack of reverence for this emblem of domestic loyalty," and thus the play "dramatiz[es] ... the godly home turned upsidedown" (388).

I shall offer further options for an actor's handling of Alice's prayerbook and its potential effect on a spectator, first in the context of how several characters deface or intend to deface other sacred or meaningful totems in the play. I do so to enter into a discussion of a phenomenological attitude the play takes pains to foreground. M. L. Wine suggests that the playwright "convey[s] to his audience the feeling of the larger powers of destiny operating on the anarchic lives of ordinary men and women" (Ixxix). He points out how the "ethical confusion ... that finally doom[s] most of the characters ... [is] reflected in how literally they use language without being aware of its 'poetic' overtones of a greater, more meaningful world of order" (Ixxx). Wine offers as an example "Alice's comparison of Arden's arms around her to 'the snakes of black Tisiphone' (xiv.144)" and explains her metaphor as "an allusion to the avenger of crime against kin that ironically eludes the speaker completely" (Ixxx). I suggest that characters may literally think about and handle objects in a way just as unaware of such "poetic overtones" or semiotic meaning - that there is an ironic gap between what the character and the playwright assert about a prop or, perhaps, even between what a character means and the prop performs.

When Mosby proposes that Clarke should fashion a poisoned "counterfeit" (1.233) of Alice's image, the text gives no evidence that she demonstrates any sensitivity to the perfidy of a gift intended to be gazed at with adoration as a means for murdering the gazer (though an actor may choose to perform gestures that do so). She does not recognize pressing semiotic associations the object would bear: how the 
object could implicate her, given it is made in her image, for instance. It is simply the poisonousness of the object that her dialogue registers, the phenomenological reality of such a device. She identifies it as "dangerous" for the reason that "thou or I or any other else, / Coming into the chamber where it hangs, may die" (235-37). She quarrels with Mosby over whether covering it with a cloth would suffice as an antidote. They settle instead on commissioning from Clarke a poisoned crucifix "[t]hat whoso look upon it should wax blind / And with the scent be stifled..." (612-13). No character speaks to the utter blasphemy of fashioning such an object, never mind wielding it, to commit murder. No character speaks to the perverse irony in disfiguring a crucifixconventionally a sacred representation of the son of God, Himself put to death, and Himself an emblem of God's promise to the faithful and devout of life after death, and the very sight of Whom alone is salvific, not lethal-as very likely many a contemporary spectator might have.

A spectator may register that dramatic irony while she watches Alice worry over how Clarke should make such a thing and not poison himself. "Well questioned, Alice" (1.626), as Mosley joins in, heightening the absurdity of the pseudo-scientific inquiry taking place. And Clarke's supposed antidotes for the crucifix's poisonous sight and stifling scent, if we imagine them being performed, are comical-a rhubarb leaf "within my nose" (630)-and very likely, ineffectual. How do "spectacles so close" (628) to one's face prevent sight of an object? The effect is less to signify the characters' motives and sensibilities and more to draw attention to the supposed efficacy or even nature of objects-a pair of spectacles and a rhubarb leaf as much as a crucifix. I propose that Alice is as careless of the conventional semiotic significations of a prayerbook as she is of those of a crucifix. 
I focus particularly on Alice's contradictory designs on the prayerbook she references in scene 8 . Line 116 , she will burn it; line 118 , she will strip and replaces its pages:

I will do penance for offending thee And burn this prayerbook, where I here use The holy word that had converted me. See, Mosby, I will tear away the leaves, And all the leaves, and in this golden cover Shall thy sweet phrases and thy letters dwell; And thereon will I chiefly meditate And hold no other sect but such devotion. (8.115-22) We have heard from Arden in scene 1 that "[I]ove letters passed 'twixt Mosby and my wife" (15). What if the actor who plays Alice enters the stage in scene 8 with those love letters in his hand, or even in his costume's pocket? What if it is these letters that Alice is meaning to burn? It is not spiritual shame that impels Alice to declare to Mosby that she "will dam that fire in my breast" (8.48) but her public humiliation at her "title of an odious strumpet's name" (72). She charges Mosby with responsibility for making her "sland'rous to all my kin. / Even in my forehead is thy name engraven, / A mean artificer, that low-born name" (75-77).

Her aspersion regarding his kinship sets Mosby on fire, and he "breathe[s] curses forth" (80) at Alice before he quits her: "I am too good to be thy favourite" (105). At the thought that "Mosby loves me not" (8.108) and that Mosby may literally be leaving, Alice changes her mind entirely and attempts to keep him there, to keep him looking at her: she will appease him and "do penance for offending" him (115). She thinks here of his letters that she was about to burn, now burning in her pocket, and, mortified, thinks to perform penance by burning the prayerbook instead. Now, given her conversion back to her own religion, wherein "Love is a god" (1.101), she lights on how she might perform a more appropriate penance right 
then and there: she will "tear away the leaves, / And all the leaves, and in this golden cover / Shall thy sweet letters dwell" (118-20). The action that seems demanded by the repetition of "leaves," and the addition of "all the leaves" in the playwright's embedded gesture directs a crescendo of emotion with which the actor handles the prayerbook as he speaks his lines and handles those leaves, perhaps even literally tearing them out, in order to make room for love letters. ${ }^{17}$ The play prompts a spectator both to judge Alice for her sacrilegious transgression and to sympathize with her, and fear for her, as she re-/disfigures her prayerbook as her desperate means of clasping a man to her who would "rid [his] hands of her" (43).

An actor who uses the prop that way dramatizes the Elizabethan preoccupation with love as idolatry. But as significant for the spectator of this scenario, the prop itself has changed, even if the actor chooses not to tear out the leaves on the stage. Sofer explains that one of the ways objects on stage move into a mode of semiotic subjectivity is when they are fetishized:

A fetishized prop is one endowed by the actor, character, or playwright with a special power and/or significance that thereafter seems to emanate from the object itself. No longer a transparent sign, a fetish takes on inordinate significance and becomes the focus of a character's projected desire, fear, or anxiety. By extension (contagion?), the object then serves the same function for the audience. (26)

\footnotetext{
17 Williamson notes that "Elizabeth I had portraits of herself and the Duke [of Anjou] inserted into her prayer book," and that "[a] prayer book is referred to as the secret container for love letters in Shirley's The Wedding" (391; n. 39). Shakespeare's Romeo and Juliet makes an analogy between wife and book cover. Lady Capulet instructs Juliet to "[r]ead o'er the volume of young Paris' face" in her effort to persuade Juliet to envision herself as wife to Paris (1.3.83): "This precious book of love, this unbound lover, / To beautify him only lacks a cover" (89-90).
} 
Alice's desire for Mosby, her anxiety over public opprobrium, her fear that he will leave her-"Look on me, Mosby, or I'll kill myself" (8.112)-are emotions that electrify that object in her hands as she transforms the prayerbook into her personalized love book.

Thomas Kyd's The Spanish Tragedy is another play that features the rude handling of a sacred totem - in this case, a sacred handkerchief, of which Veronica's handkerchief, imprinted miraculously with the image of Christ's face, is an example. Sofer offers an alternative reading to Huston Diehl, who, in support of her thesis that Elizabethan drama functioned to "demystif[y] the power of idolatrous images by exposing their potential to deceive the credulous onlooker," offers The Spanish Tragedy and Othello as plays that "dramatize the deceptiveness of supposedly magical handkerchiefs" (Sofer 74). ${ }^{18}$ Sofer argues instead that Kyd

exploited spectators' residual faith in magical handkerchiefs and longing for ocular experience by transforming the handkerchief from a token of all believers' salvation into a personalized fetish that embodies the principle of private vengeance ("Remember you must kill"). (75)

Likewise, we can see how Arden's author transforms not a handkerchief, here, but a prayerbook "from a token of all believers' salvation into a personalized fetish that embodies the principle" of idolatrous love. But unlike Kyd's tragedy, Arden also transforms a prop back into "a token of all believers' salvation." Alice performs penitence with the help of a prop twice in this play. I trace this play's second transformation of a prop-a kind of consubstantiation via the theatre's Corpus Christi affect-its implications for Alice, and its potential affective consequences for the spectator, by

18 Staging Reform, Reforming the Stage: Protestantism and Popular Theater in Early Modern England. See especially chapters 4 and 5. 
turning to Alice's husband, whose body provides the materials for what will become a prop.

Arden opens with Thomas Arden expressing his melancholy. A spectator is prompted to sympathize with Arden for his grief over his wife's infidelity and to fear for his dramatically ironic heedlessness of her nefarious schemes to murder him. However, the same spectator might later be prompted to judge Arden for his ruthless response to Dick Reede. "For Christ's sake" (13.17), the latter pleads on behalf of his wife and children for the return of the lands that Arden was given "[b]y letters patents from his majesty" (1.4). Arden condemns Reede for his "clamorous impeaching tongue" and threatens retribution if Reede continues to "rail": "I'll banish pity if thou use me thus" (13.22-27).

Arden's is a noticeably un-Christian response to the needy and dispossessed, particularly since it is Arden's good fortune that dispossessed Dick Reede of his. And good fortune appears to protect Arden over the course of the play, as he eludes his would-be murderers' hands until the evening of his last supper. What is more, Arden's escapes, of which he is blithely unaware, are described by witnesses in terms of religious salvation. Shakebag and Black Will are about to attack Arden on the road when Lord Cheyne appears and interrupts their plans: "Arden, thou hast wondrous holy luck" (9.133), Will complains, and Greene greets news of this yet one more escape with: "The Lord of Heaven hath preservèd him" (142). Scene 14 opens with Will marvelling to "Sirrah Greene, when was I so long in killing a man?" (1), and he concludes, "doubtless, he is preserved by miracle" (14.2829). Alexander Leggatt wryly notes that "[f]ate in [Arden's] tragedy ... is not so much inexorable as perverse," remarking that "just as we ourselves have begun to wonder if Arden leads a charmed life, he is killed" (129). And his death is a charmed death, too, so to speak, for the play transforms 
Arden's corpse into a stage prop that functions to invoke phenomenologically something between the "felt absence" and the "real presence" (Sofer 27) of Christ's bloody body, at once an alarming and wondrous, idolatrous and salvific image.

The materials with which the play works to conjure its staging trick are the semiotic effects and affective qualities of stage blood, in part produced by meanings that are historically construed. In the medieval Corpus Christi Passion plays, "Christ's body was covered not only with blood and sweat but often with spittle and mucus as well" (Sofer 70), and his blood "is both curative and salvific" (80). The N Town Passion Play II, for instance, depicts the circumstances of extreme physical abuse whereby Jesus's body would be brought to such a condition: Jesus is both beaten about the head and spat at by order of Annas and whipped by order of King Herod (Medieval Drama, 160.1-3; 440.1). In the York play, Christ's Death and Burial, evidence is shown of the curative and the salvific effects of Christ's blood: "[The blind Longeus goes to Jesus and pierces his side with the spear, and suddenly gains his sight]" (299.1-2). Longeus subsequently affirms: "Full spitously spilte is and spente / Thy bloode, Lorde, to bringe us to blis / Ful free" (306-8). The Centurion sees this event, names it a miracle and evidence of Jesus's mercy-"O wondirfull werkar, iwis, / ... / Trewe token I trowe that it is / That mercy is mente unto man" (313-16)-and avows his belief that Jesus is truly "Goddis sone" (322-23). In his discussion of how the Corpus Christi plays exploited "ocular experience," Peter Travis makes note of a "psychological phenomenon, often known as 'affective piety,' ... documented in numerous records from the late Middle Ages, " whereby "medieval viewers were often convinced that before their 
devoted gaze sacred icons came alive to perform anew their wondrous deeds" (17). ${ }^{19}$

Arden insistently makes unlikely connections between the prosperous, if unscrupulous and ruthless landlord and merchant, Arden, and Jesus Christ. Arden is murdered over a game of dice, the very "silver dice," perhaps, he used to toss with Alice "for kisses" (1.123-24). A spectator may be reminded of Judas, who delivered Jesus to the chief priests, thus to his death, for 30 pieces of silver (Matt. 26.15), or of the soldiers at the foot of Christ's cross, "casting lots" for His garments (Mark 15.24). Arden is struck or stabbed by three assailants-Mosby, Shakebag, and Alice-an echo of Christ's three-times being denied by Peter (Matt. 26.33-35; 69-75). While editors Wine, and McLuskie and Bevington after him, isolate textual prompts for actions on behalf of the murderers that would account for three stab wounds inflicted upon Arden (14.235.1; 236.1; 238.1 / 14.232.1; 233.1; 235.1), the text can support the infliction of five wounds, wounds that thus parallel the number Christ received on the cross: two hands, two feet, and his side. ${ }^{20}$ And whether the instruments with which he is killed are swords or knives or perhaps some blunt instruments - the text is silent on this - the result is that he is extensively beaten and bloodied.

Sofer argues that one of the ways in which "props come to life on stage [is] when they confound dramatic convention. A prop takes on a life of its own ... when it refuses to act proppily" (28). Similarly, Orlin makes note of the "performance of things" when "[t]hey resist certain control"

\footnotetext{
${ }^{19}$ Dramatic Design in the Chester Cycle. See also Clifford Davidson's "Sacred Blood and the Late Medieval Stage."

20 1st-Mosby: " 'Now I can take you' " (14.232); 2nd-Mosby: "There's for the pressing iron you told me of" (235); 3rd-Shakebag: "And there's for the ten pound in my sleeve" (236); 4th and 5th-Alice: "Take this for hind'ring Mosby's love [her first stab] and mine [her final]" (238).
} 
(191). The blood that Arden sheds does not behave as it should and resists the control of two characters on stage. Alice orders Susan to "wash away this blood," but Susan's response after trying to do so-"The blood cleaveth to the ground and will not out" (14.254-55)-indicates that the blood resists her handling. "But with my nails I'll scrape away the blood," Alice counters, but she finds, "The more I strive, the more the blood appears!" (256-57). Alice and Susan "open the countinghouse door and look upon Arden" (14.327.1-2). Notice how Alice instructs Susan with her imperative, "See," to gaze upon the condition of Arden's body, a vision that recalls the beaten and scourged body of Christ on his way to crucifixion, an ocular experience, perhaps, that may trigger a state of affective piety in the way of stages past: "See, Susan, where thy quondam master lies / Sweet Arden, smeared in blood and filthy gore" (14.328-29)a bawdy body if you will (OED v. obs.). When the Mayor enters the house, he says, "Look in the place where he was wont to sit. - / See, see! His blood! It is too manifest" (4001). Alice responds, "It is a cup of wine that Michael shed," and Franklin retorts, "It is his blood, which, strumpet, thou hast shed" $(402,404)$. The play depicts a confrontation over the ontological status of the misbehaving blood/wine on the stage floor and so conjures the forbidden Catholic sacrament of Communion where sacramental wine is perceived to be transformed into the blood of Christ, shed for the salvation of mankind. In so doing, the play begins to overlay its own representation of a historical murder mystery solved and a murderer condemned by the evidence-a dead body and blood on the floor-with the outlawed medieval drama created to affirm and celebrate that miraculous sacramental transformation.

In scene 16, the Mayor admonishes Alice, "See, Mistress Arden, where your husband lies. / Confess this foul fault and be penitent." Alice replies, "The more I sound his name, the 
more he bleeds. / This blood condemns me and in gushing forth / Speaks as it falls..." (1-6). In Richard III, Lady Anne calls out to her retinue, "O gentlemen, see, see dead Henry's wounds / Open their congealed mouths and bleed afresh" and so condemns Richard, whose "presence," Anne charges him, "exhales this blood / From cold and empty veins" (R3, 1.2.5357). But in Arden, the blood of Arden's corpse not only condemns; like the blood of the living Christ in the Corpus Christi plays, it appears to be salvific, and it appears to save Alice.

When Alice addresses Arden's corpse directly, when she fetishizes that body with her emotions-her contrition, her repentance, her desire for salvation-her character's response to the dead body on the floor begins to align with the play's affective presentation of that dead body. As Alice sees and hears the blood condemn her, she asks for forgiveness, declares her repentance, and calls out in the imperative, as if she could command the very Christ-like resurrection of that body, a phenomenally live body of an actor, to "[r]ise up, sweet Arden, and enjoy thy love..." (16.9). Once again Alice invests an object with inordinate meaning, fetishizing, this time, a dead body with her desires and anxieties: "...frown not on me when we meet in heaven!" (10). And the text validates her faith in her salvation: Bradshaw pronounces in scene 18, "Mistress Arden, you are now going to God, / And I am by the law condemned to die..." (18.2-3). She replies, "let me meditate upon my Saviour Christ, / Whose blood must save me for the blood I shed" (10-11). The Corpus Christi affect operates at full force here: semiotically, the boy actor represents Alice Arden, an adulteress and murderer, and relates to the prone adult actor playing Thomas Arden as representing the corpse of Alice's murder victim. A spectator is here invited to judge and condemn Alice, and so the play stages precisely what the title-page says the play offers: "Wherin is shewed the great mal / lice and discimulation of a 
wicked wo- / man, the vnsatiable desire of filthie lust / and the shamefull end of all / murderers." At the same time, the play offers a spectator another way to see/feel: with the boy actor as her surrogate devotional spectator, she may partake of an affective experience of consubstantiation, should she accept it, to see Christ's bloodied body disclosed to her. As Alice looks upon a bloodied body and finds salvation, so may the play's spectator experience catharsis by wonder and participate in a drama of salvation. If Elizabethan and Jacobean tragedy worked to demystify the efficacy of sacred and devotional images, as Diehl argues; if "for Kyd it was necessary to travesty sacred objects in order to reclaim them for his sensational theater," as Sofer argues (87); then Arden's author restored to English spectators a prop with "devotional efficacy as salvific ocular experience" (72). Arden of Faversham reclaims for the blood that shed so plentifully on the early modern stage its magical, even miraculous, property. 0

\section{Works Cited}

Arden of Faversham. Plays on Women. Ed. Kathleen E.

McLuskie and David Bevington. Revels Student Editions. Manchester: Manchester UP, 1999. 269-348. Print.

Barish, Jonas. The Antitheatrical Prejudice. Berkeley:

Berkeley UP, 1981. Print.

"Bawdy." The Oxford English Dictionary. 2nd ed. 1989.

The Bible: Authorized King James Version. Ed. Robert Carroll and Stephen Prickett. Oxford World's Classics. Oxford: Oxford UP, 1997. Print.

Brook, Peter. There Are No Secrets: Thoughts on Acting and Theatre. London: Methuen, 1993. Print. 
Davidson, Clifford. "Sacred Blood and the Late Medieval Stage." Comparative Drama 31.3 (Fall 1997): 436-58. Web. 6 Feb. 2012.

Dawson, Anthony B. "Performance and Participation:

Desdemona, Foucault, and the Actor's Body."

Shakespeare, Theory, and Performance. Ed. James C.

Bulman. London: Routledge, 1996. 29-45. Print.

Diehl, Huston. Staging Reform, Reforming the Stage:

Protestantism and Popular Theatre in Early Modern England. Ithaca: Cornell UP, 1997. Print.

Fraser, Russell A. "Introduction." Drama of the English Renaissance. Vol. 1. The Tudor Period. Ed. Russell A. Fraser and Norman Rabkin. New York: Macmillan, 1976. Print.

"Iconoclasm." Oxford Dictionary of Philosophy. Ed. Simon Blackburn. Rev. 2nd ed. Oxford: Oxford UP, 2008. 177. Print.

Leggatt, Alexander. "Arden of Faversham." Shakespeare Survey: An Annual Survey of Shakespearian Study and Production 36 (1983): 121-33. Print.

Martin, Randall. "Notes." Henry VI, Part Three. By William Shakespeare. Ed. Randall Martin. Oxford World's Classics. Oxford: Oxford UP, 2001. 228. Print.

McLuskie, Kathleen E. and David Bevington. "Notes." Arden of Faversham. Plays on Women. Ed. Kathleen E. McLuskie and David Bevington. Revels Student Editions. Manchester: Manchester UP, 1999. 269-348. Print.

Medieval Drama. Ed. David Bevington. Boston: Houghton, 1975. Print. 
Mooney, Michael E. Shakespeare's Dramatic Transactions. Durham: Duke UP, 1990. Print.

O'Brien, Ellen J. "Mapping the Role: Criticism and the Construction of Shakespearean Character." Shakespearean Illuminations: Essays in Honor of Marvin Rosenberg. Ed. Jay L. Halio and Hugh Richmond.

Newark: U of Delaware $P, 1998.13-32$. Print.

O'Connell, Michael. The Idolatrous Eye: Iconoclasm and Theater in Early-Modern England. Oxford: Oxford UP, 2000. Print.

Orlin, Lena Cowen. "The Performance of Things in The Taming of the Shrew." The Taming of the Shrew: Critical Essays. Ed. Dana E. Aspinall. Shakespeare Criticism. New York: Routledge, 2002. 186-209. Print.

Shakespeare, William. All's Well that Ends Well. Ed. Susan Snyder. Oxford World's Classics. Oxford: Oxford UP, 1993. Print.

---. Henry VI, Part Three. Ed. Randall Martin. Oxford World's Classics. Oxford: Oxford UP, 2001. Print.

---. Romeo and Juliet. Ed. Jill Levenson. Oxford World's Classics. Oxford: Oxford UP, 2000. Print.

---. The Tragedy of King Richard III. Ed. John Jowett. Oxford World's Classics. Oxford: Oxford UP, 2000. Print.

Snyder, Susan. "Notes." All's Well that Ends Well. Ed. Susan Snyder. Oxford World's Classics. Oxford: Oxford UP, 1993. 122. Print.

Sofer, Andrew. The Stage Life of Props. Ann Arbor: $U$ of Michigan P, 2006. Print. 
States, Bert O. Great Reckonings in Little Rooms: On the Phenomenology of Theater. Berkeley: $\mathrm{U}$ of California $\mathrm{P}$, 1985. Print.

Tassi, Marguerite A. "Scandalous Counterfeiting: Iconophobia, Poison, and Painting in Arden of Faversham." The Scandal of Images: Iconoclasm, Eroticism, and Painting in Early Modern English Drama. Selinsgrove: SUP, 2005. 130-51. Print.

Teague, Frances N. Shakespeare's Speaking Properties. Lewisburg: Bucknell UP, 1991. Print.

The Tragedy of Master Arden of Faversham. Ed. M. L. Wine. The Revels Plays. London: Methuen, 1973. Print.

Travis, Peter. Dramatic Design in the Chester Cycle. Chicago: $U$ of Chicago $P, 1982$. Print.

Williamson, Elizabeth. "The Uses and Abuses of Prayer Book Properties in Hamlet, Richard III, and Arden of Faversham." ELR 39.2 (Spring 2009): 371-95. Web. 6 Feb. 2012.

Wine, M. L. "Introduction." The Tragedy of Master Arden of Faversham. Ed. M. L. Wine. The Revels Plays. London: Methuen, 1973. xix-xcii. Print.

Bernice Mittertreiner Neal is a PhD candidate at York University in the Department of English. Her research focusses on how stage properties perform in ways that intervene in the problems of representing female desire on the early modern transvestite stage. She also teaches Modern Drama. 